\title{
THE IMPORTANCE AND PREVALENCE OF MODERN FORMS OF STAFF TRAINING IN THE CORPORATE ENVIRONMENTS OF TRANSITION COUNTRIES: THE CASE OF SLOVENIA
}

Tanja Markovič-Hribernik, Bostjan Jarc *

\begin{abstract}
Compared with traditional forms of education and training, e-learning is gaining increasing importance not only within the academic setting of formal education, but also in the corporate environment. Concerning the latter, it is evident that with increasing pressure on cost efficiency and competitiveness, in addition to the current harsh financial and economic conditions, companies are being challenged and this tends to change their behaviour patterns. In this article, the results of a survey are presented. The survey focused on the current status and possible future trends of corporate e-learning methods in Slovenia, which is among the so-called transition countries. This survey brings more than one aspect of this issue to light. The findings show increasing rates of acceptance of the e-learning education model by the local corporate environment. Nevertheless, significant gaps are evident when compared with the most advanced European and worldwide economies in terms of the widespread use of comprehensive e-learning models and the latest e-learning technologies, such as LMS systems. Furthermore, the survey reveals that e-learning is perceived by companies as cost efficient and flexible, but on the other hand it is not yet perceived to contribute to a higher quality level of staff training when compared with traditional methods.
\end{abstract}

Keywords: staff training, e-learning, corporate environment, transition countries

JEL: O33, P20, M53

\section{INTRODUCTION}

Good training is crucial in the successful development of any society, business or institution. However, challenged by the current crisis, companies are inclined to rationalize and optimize their budget, which often includes changes to the crucial area of employee training. In addition to financial issues, employees have a lack of time due to busy schedules, as well as an increasing amount and complexity of work. Highly dynamic business and macro-economic environments require flexibility in all of these aspects. Consequently, companies face the challenge of optimizing employee training. E-learning is gaining in market share, with increasing relevance as a training method.

In the US particularly, but also in major European economies, e-learning appears to be widely promoted, advanced and gaining in popularity in corporate environments. Much less is known about how widespread the use of e-learning is in transition countries and their business environments. For this purpose, the present survey was conducted and focused on companies and other organizations in Slovenia. The aim of this research was to establish the current situation and possible trends to expect in future years. Companies were included in the survey regardless of their size or activity. The survey was distributed to 423 corporate and institutional addresses in Slovenia, of which 70 responded and participated. The survey was carried out in November 2012.

The following section is focused on the concept of elearning itself and the scope for the use of this term. Recent

\section{* Tanja Markovič-Hribernik, Ph.D}

Associate Professor

University of Maribor, Faculty of Economics and Business,

E-mail: tanja.markovic@uni-mb.si

\section{Bostjan Jarc}

e-learning consultant

B2 d.o.o. Maribor

E-mail: bostjan.jarc@b2.eu; bostjan.jarc@gmail.com 
relevant studies are listed and reviewed in section 3 . Section 4 reveals the methodological framework used for this study, while in section 5 data concerning the characteristics of the included companies is presented. Section 6 is dedicated to the research results and comments. The final conclusions are presented in section 7 .

\section{THE CONCEPT OF E-LEARNING}

In both literature and everyday practice, the term "elearning" is not always used in the same way (see for example Bachman (2000); Elearning - What is E-learning (2012); Defining e-learning (2012)). Terms like distance learning, e-learning, Web Based Training (WBT) and Computer Based Training (CBT) are often used synonymously. The European e-Learning Action Plan (Commission of the European Communities 2001) defines e-learning as a form of education that uses the latest multimedia technologies and internet to upgrade the quality of education, allowing access to new sources and services, as well as knowledge exchange and collaboration (see also Gardner and Bryn 2006, p. 14). The Utah Training Network sourced Ed Technology Glossary of Terms (2012) defines e-learning as simply "education by means of electronics." This latter concept encompasses a wide range of applications and processes, such as Web Based Training (WBT), Computer Based Training (CBT), Virtual Classrooms and Digital Collaboration. It also includes web-based data transfer (LAN/WAN), audio and video media (CD, DVD), transmission by satellite, interactive TV, etc.

With so many definitions and concepts of e-learning in both professional literature and everyday practice, we have opted for the widest possible definition of e-learning to be used for this research. In the list below are some of the concepts described in literature that are relevant for the objectives of our research:

- learning via websites. This is self-directed searching for knowledge and learning through ordinary web pages and represents the lowest level of e-learning;

- learning using CD or DVD media and similar; this model is not usually supported by tests of understanding nor does it enable communication among participants;

- Blended Learning, combining traditional methods and different forms of e-learning; it combines the benefits of both traditional methods and elearning. According to past surveys, such as the CrossKnowledge Survey (2012), this is the most common form of e-learning, with as many as $76 \%$ of European companies using this form;

- A Webinar combines what the name suggests: the World Wide Web with a seminar. Internet technologies are usually accessed for this form of e-learning and they can also enable assessment of the candidate's level of understanding (Howstuffworks 2012);

- Video conference; although this appears closely matched to the concept of a webinar in terms of the technologies used, these two forms of e-learning are largely unrelated in terms of their process. A video conference allows communication among a smaller number of "equals", while a webinar is available for a larger number of participants, and features primarily one-way communication from the lecturer towards the audience;

- E-courses include learning material that is distributed to users electronically. For the purposes of issuing and distribution, an e-learning management system is required, usually referred to as a LMS (Learning Management System);

- Guided e-course or e-learning, where a mentor guides the learning process; this model makes use of different e-learning formats and is supported, counselled, motivated, supervised and guided by a mentor;

- E-mail: As an educational tool, this format experienced great expansion at the time the Internet emerged; its prevalence on the global market is now negligible;

- E-books: This tool is intended for the transfer of information and independent training. Nevertheless, it does not qualify as a very advanced e-learning product;

- Mobile learning is carried out using mobile devices (Unesco 2012);

- E-testing: although it cannot be qualified as an educational model directly, it may be considered a viable supportive or complementary service to traditional training methods and/or e-learning;

- Comprehensive e-learning supported by an LMS system: systems that also enable the production and development of e-learning content (usually in the form of an e-course), are called LCMS, which stands for Learning Content Management System. The comprehensive e-learning concept, use of an L(C)MS and the integration of e-learning with other business processes is the most advanced form of e-learning for corporate environments. This applies not only to the technology it incorporates but also the way in which the e-learning is organized and processed. These features enable this model to become an integral part of any corporate training system. By itself, an LMS represents only the basis of the comprehensive corporate e-learning system. It is complemented with e-learning content (e.g. e-course) and supporting (organizing, mentoring, etc.) services.

- Social e-learning is a relatively new concept but has already achieved significant progress, especially in the US corporate training market. Social e-learning is both designed and distributed by using web tools, most often blogs, bookmarks and social networks. Special tools (Yammer, Mzinga, etc.) dedicated to corporate social e-learning are currently in the process of development (Hart 2009). 


\section{REVIEW OF RECENT RELEVANTSTUDIES, KEY CONCLUSIONS}

In recent years, several studies on these topics have been undertaken within major markets where e-learning has already gained its place as an established form of corporate training. Among the most recent work, research done by Adkins (2011) is worth mentioning. This global study looks at e-learning products and services for self-paced e-learning, their current situation and future trends on the global e-learning market. Although the aspects of the focus of this research are not directly relevant to our aims, a number of key conclusions reveal some interesting facts about global trends. The study reports that the total global e-learning market reached US\$32.1 billion in 2010, but will increase to $\$ 49.9$ billion by 2015 . The highest growth rates should be achieved by markets in Asia (28.4\% yearly), which are set to pass the Western European market by 2015. The next highest growth rate is in Eastern Europe, which should reach growth rates of above $20 \%$ per year. The study also found that e-learning is thriving in academic environments, with market shares here higher than in the respective corporate environments of all countries except the US.

More closely related to our aims is the research of Overton and Dixon (2011), which looks at the use of training technologies by European companies. The study was carried out for one of the world's largest e-learning conferences, Berlin Educa. The findings revealed that the most frequently used technologies by European companies are web questionnaires (81\%), e-learning courses, virtual meetings and training portals. More than $60 \%$ of participants used a LMS and more than 50\% were using it integrated with their internal human resource systems. The study also reported that Cloud based e-learning and mobile training are both expected to have the brightest futures. The authors find that generalist and IT-oriented content is predominantly what companies demand for staff training. More specific content is related to company business analysis, customer relations management, social responsibility, and sales and marketing. As expected, use of content related to communication skills, teamwork and collaboration is lagging behind. When asked about the main benefits of e-learning methods, European companies report: more efficient implementation of the latest IT systems; a wider range of available educational content; easy access to relevant content; considerably reduced rates of absenteeism; greater flexibility in education; shorter response time to changes in the business environment; and, last but not least, cost efficiency. Half of companies also state that e-learning has done much to improve their customer satisfaction and productivity. The survey also exposed some of the main obstacles for implementation of e-learning models: employees in organizations appear to lack the knowledge and skills to design their own training process, while their training managers lack the knowledge and skills needed for the implementation of these methods in their companies; executives generally appear to be reluctant to introduce new methods; the costs of arranging an e-learning system, etc.

In this section, a lot of attention has been given to the survey by Overton and Dixon (2011), as our assessment of the situation in Slovenia will later be compared primarily with these findings. However, it should be noted that the comparison is difficult in some respects. In particular, when considering the most advanced e-learning technologies, such as Learning Management Systems, usage rates depend very much on average company size. The average Slovene company is far smaller than those of Western Europe and this has an influence when assessing how widespread the use of these methods might be.

It is also worth mentioning a recent survey by Cox eLearning Consultants, LLC (2011), who analyzed companies and organizations from 55 countries worldwide, regardless of their size or activity. The purpose of this study was to examine staff training solutions and methods utilized by businesses and other organizations, and what trends were expected for the near future. The survey was limited to social learning, video training, mobile learning and web conferencing e-learning techniques. Findings show that organizations are increasingly using web-based CPC conferencing systems, as well as learning methods supported by video (CPC video based training). However, the biggest shifts are expected in mobile learning and social media supported training.

With regard to our research aims, the findings of the study by CrossKnowledge (2012) - 1st European e-learning Barometer - should also be considered. The work was conducted in 2011 with 511 companies from 6 European economies: the UK, France, Spain, Italy, Belgium and the Netherlands. The following is a summary of the key findings:

- In the UK, Spain and Benelux nearly $40 \%$ of companies train more than $50 \%$ of their employees via e-learning (in France only 17\%). E-learning is most used within the services sector ( $43 \%$ of service-based companies train more than $50 \%$ of their employees via e-learning). British companies, despite having used e-learning for less time than other countries, are quickly developing their application of e-learning (in 2011, 51\% of companies delivered at least one training via e-learning to over $50 \%$ of their employees compared to $39 \%$ in 2010). Regarding size, large companies have been using e-learning the longest (68\% of the European sample of companies that use e-learning have a headcount of over 10,000).

- The factors that motivated large companies to develop an interest in e-learning ahead of the rest include the challenge of training large numbers of employees, the need to align competencies in real time over increasingly competitive global markets and economies of scale.

- The vast majority of companies surveyed spend less than $10 \%$ of their total training budget on e-learning. The main goal of e-learning is training cost optimization - delivering a consistent quality of training to large numbers of employees accounts for $37 \%$ of use.

- $75 \%$ of companies use e-learning to deliver training on core professional skills, e.g.IT and desktop training, as well as Health and Safety or Compliance 
training. In large companies there is a clear rise in themes such as management, leadership, communication and personal development. The study also underlines the link between the length of time that a company has been using e-learning and the sophistication of the modules and delivery methods that it makes available.

- For $76 \%$ of companies, the most popular delivery method for e-learning is Blended learning (47\% of those already using this approach are planning to intensify usage).

- Regarding the near future, many companies answered that they are seeking to maintain or cut back their overall training budget and to reduce cost per learner in order to be able to train a greater number of employees without increasing spending on training.

The history of e-learning in Slovenia is considerably shorter than in the major US and European economies, so the record of past research is rather modest. To date, studies have focused mainly on formal education and school related e-learning methods, rather than corporate environments. As an example, Vehovar (2007) analyzed the e-learning systems of the new EU-members, including Slovenia. Although the research covers e-learning in relation to both formal and non-formal education, most of its findings are related to the academic industry (schools) rather than the corporate environment.

One of the few surveys to focus on the corporate environment was that of the Eizobrazevanje.net portal, conducted in the first months of 2011. The sample consisted of 73 participating companies. However, this survey was limited to companies in a few selected industries that had a workforce of at least 100 people. The survey did not provide information on the impact of the use of e-learning methods on business development.

Use of e-learning in the Slovene corporate environment was investigated by Arh, Kovačič and Jerman-Blažič (2006). The authors write that the recent rise of e-learning in Slovenia is the result of a growing choice of various e-learning services and systems, their use elsewhere in Europe, and the availability of financial resources from the EU and its Structural Funds. The authors state there is increasing use of independent e-learning models using e-content as well as combined e-learning models supported by a mentor. The findings also revealed that e-learning is still mostly reserved for larger companies, despite the evidence of benefits for small and medium businesses. Like the study by Vehovar (2007), this study shows that, in general, the role of the mentor is considered crucial for the e-learning process. According to Vehovar, the educational approach in Slovenia is closely associated with social, cultural, economic and historical factors.

Historically, for over 500 years, the Habsburgs ruled the Slovenian territory. This influence can still be seen in the current approach to education. In the past, teachers had a largely authoritarian role, lecturing their disciples who remained passive as learners. Communication and collaboration were essentially absent from the process. Traces of this idea, with the teacher in an authoritarian role, remain present when speaking of modern e-learning methods. Therefore, for successful implementation, a combined model of education featuring both traditional and modern e-learning processes will be necessary (Vehovar 2007, p. 25).

\section{METHODOLOGICAL FRAMEWORK}

A questionnaire was produced for the purpose of this study, supported by the FluidSurveys.com online survey tool. Its modelling was based on other questionnaires already used for similar research (e.g. Overton and Dixon 2011; Eizobraževanje.net 2011). The questionnaire consists of 19 questions, divided into four segments (see the Appendix for details):

1. General information on the company - company characteristics, industry, number of employees, number of branches and locations, etc.

2. Company staff training system - training resources, tools, responsible persons, frequency, etc.

3. E-learning - e-learning resources, tools, existing elearning techniques, benefits, comparison to traditional training methods, obstacles to implementation, impact on business development, etc.

4. Future trends - planning of e-learning development

The questionnaire was mailed to 423 employees of small, medium and large enterprises and organizations in Slovenia. The survey was conducted in November 2012. Included in the database were mainly: human resource managers and personnel; IS/IT managers and experts; training managers; managing directors; and other company executives. This web survey aimed to obtain answers from the relevant persons responsible, i.e. those who were embedded in the educational processes of their respective companies and organizations. As previously discussed, there was a potential risk from different interpretations of e-learning by the respondents. For this reason, we decided to use the broadest possible definition of the e-learning concept, which not only includes use of the most advanced forms of e-learning (such as LMS), but also its more basic forms, including the use of e-mail for training purposes.

A branching scenario was applied to the questioning procedures of this survey, as demonstrated by question 8: "How long have you been using the e-learning methods in your organization?" A decision loop was included here to steer additional questions according to the respondent's answer. If this was "We do not use e-learning at all", no further details were asked and participants were directed toward questions on future plans. 


\section{SAMPLE DATABASE AND FUNDAMENTALS}

\section{Segmentation of companies by size and activity}

\section{Companies' main sector of activity as per SKD (2008)}

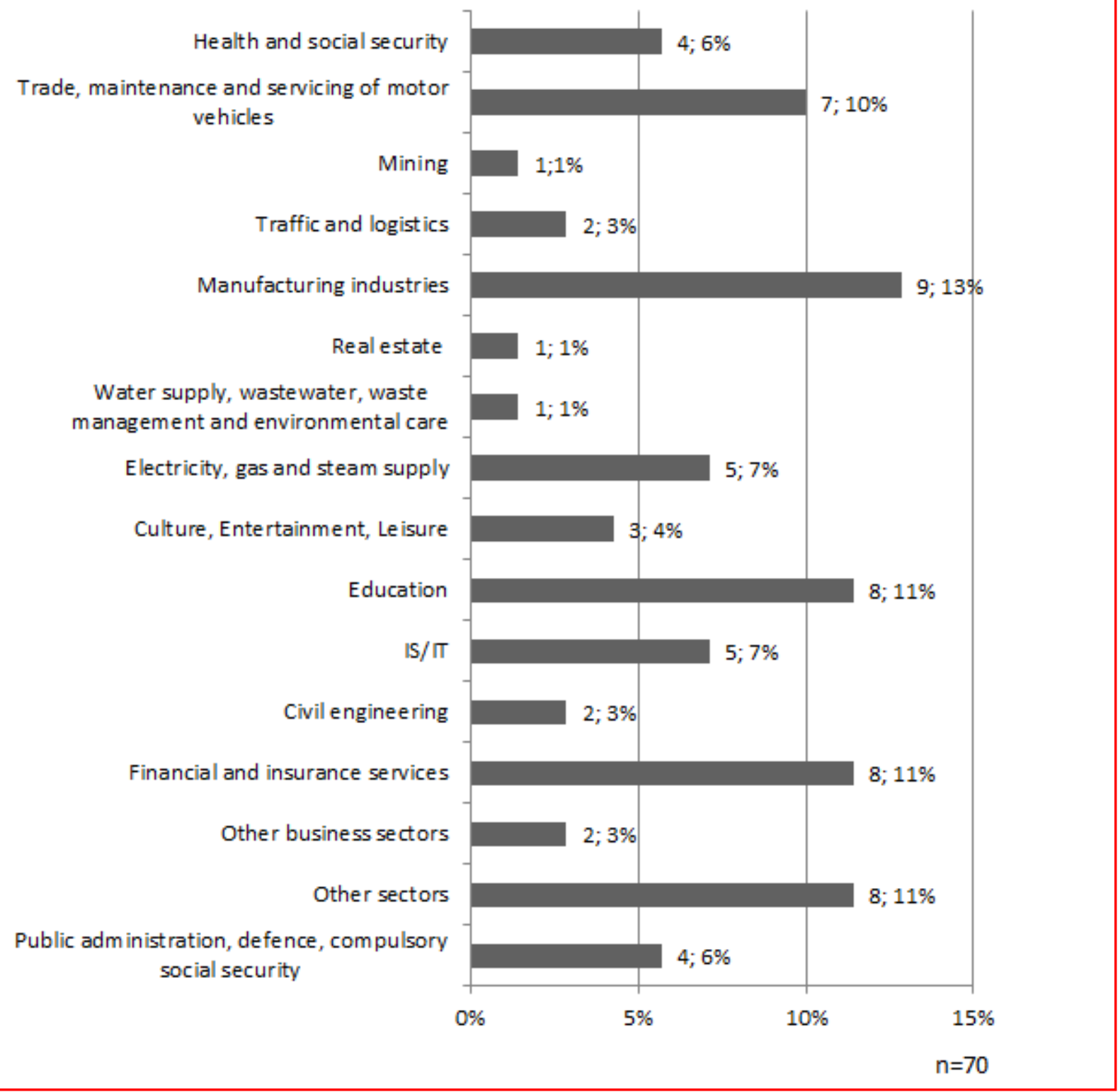

Data source: Web Survey

Figure 1: Companies by their principal activity (Standard Sectorial Classification, 2008)

The database features organizations of all sizes and industries. As seen in Figure 1, 70 companies and other organizations participated. The majority were from the manufacturing industry (13\%), followed by financial and insurance services, education and other sectors ( $11 \%$ each). Companies from 16 different industries participated. Therefore, the sample can be considered adequate and sufficiently diverse to represent the entire corporate environment of Slovenia. Both private and public sectors were included.

As shown in Figure 2, most of the participating companies (24\%) employed between 101 and 250 people at the time of the survey. Companies with less than $50 \mathrm{em}-$ ployees accounted for $10 \%$ of the sample. From our point of view, the latter could prove to be the least suited to integrate the most advanced forms of e-learning.

Nineteen percent of participating companies (corresponding to 13 subjects out of 70 ) employed over 1,000 staff. In comparison to the overall number of companies of this size, these 13 participants present a highly weighted sample; following 2010 statistics, there were 26 business 
companies of this size in Slovenia (Delo. si 2010). As the current financial crisis has proved to be fatal for many large companies, especially from the civil engineering sector, this number might now be even lower. When we include public administration organizations and institutions with over 1,000 employees to this statistic, the weighting of this sample can still be considered great.

As expected, the analysis shows that most companies featuring external branches and business premises (e.g. retail subsidiaries, branch offices, production sites, etc.) belong to the category of 1,000 or more employees (Figure 3). Thirty one percent featured 50 or more locations. Only $8 \%$ of companies this size (corresponding to 1 in our sample) have no off-site business premises.

The applicability of the most advanced e-learning technologies (such as LMS) is largely dependent on company size and the geographical dispersion of its premises.

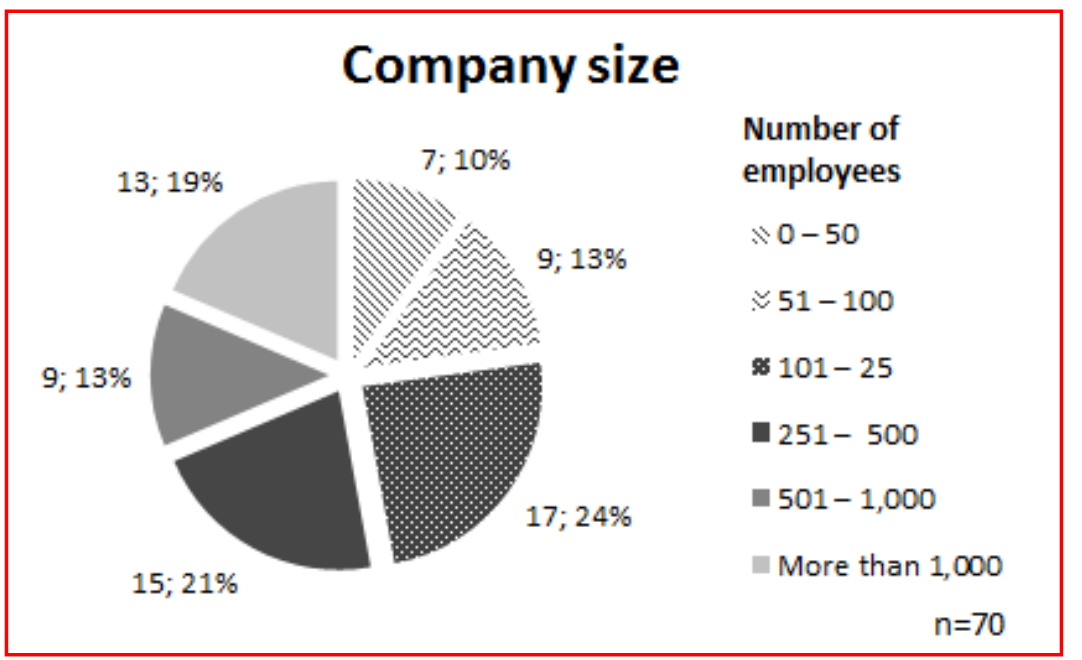

Data source: Web Survey

Figure 2: Companies by size

\section{Share of companies by number of locations or branches per category of size}

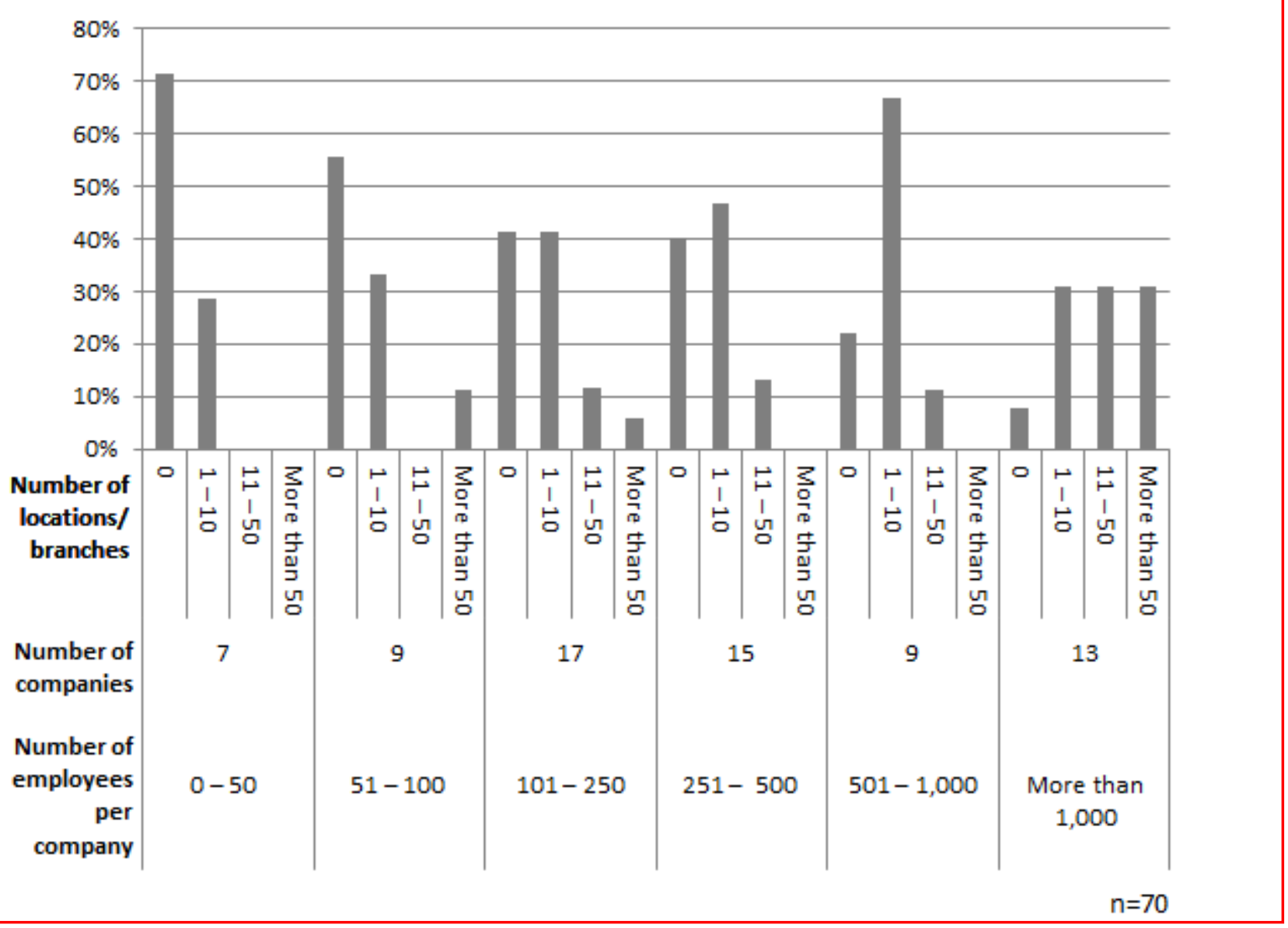

Data source: Web Survey

Figure 3: Number of locations by company size 
Therefore, these large companies may be considered most suited to the use of advanced e-learning models.

\section{Characteristics of respondents}

As shown in Figure 4, most responses came from human resource managers $(42 \%)$, followed by "other positions" (30\%) and heads of departments (23\%). Considerably fewer responses were from IS/IT managers, managing directors or board members, representing 5\% combined.

The category "other positions" includes the following profiles: staff training member; assistant director; responsible for organization training; advisor; joint services staff members; training manager; project manager; and staff responsible for the remuneration system.

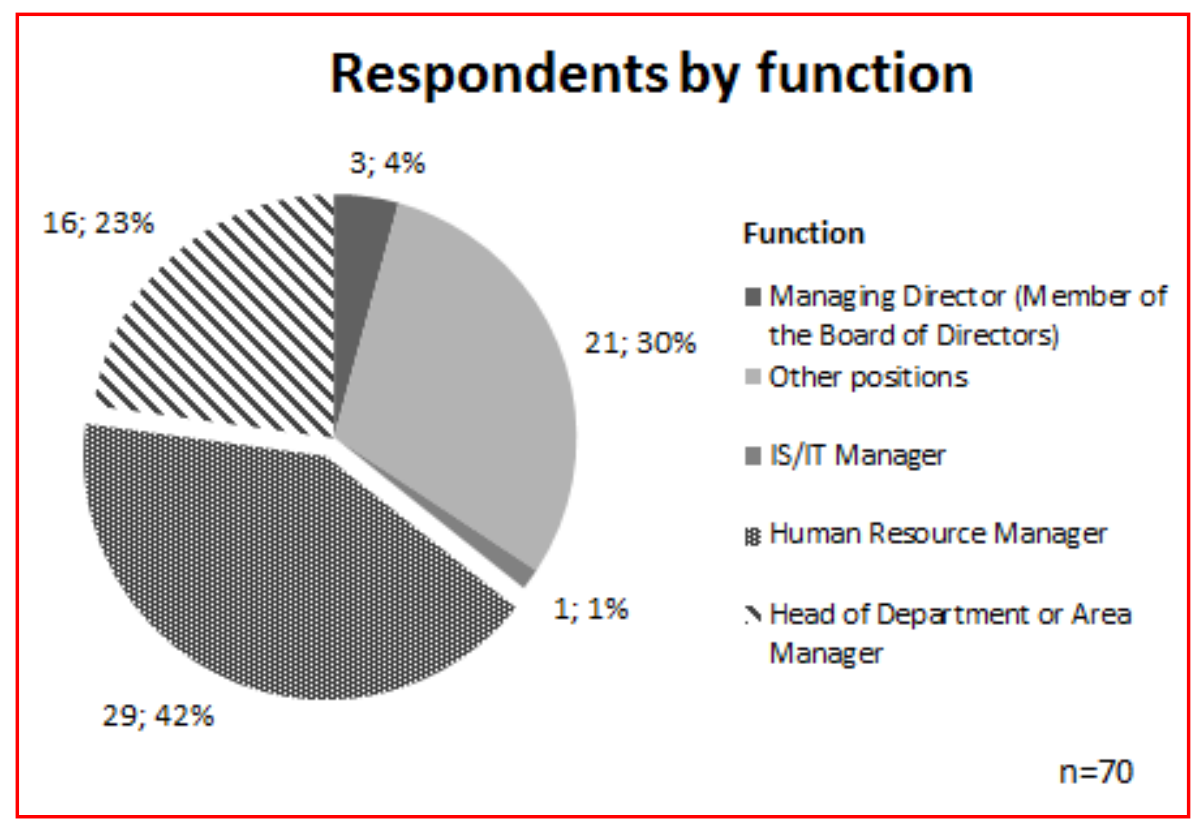

Data source: Web Survey

Figure 4: Respondents by function

\section{SURVEY OUTCOME ANALYSES \\ Training planning and resources}

The multiple choice question: "Who is responsible for planning employee training in your company?" allowed multiple replies. The outcomes shown in Figure 5 reveal that this planning is mostly performed by the department head (39\%) or human resources staff (28\%). Surprisingly, IS/IT departments appear to be mostly absent from the planning process. Their active participation might be expected due to the intense use and development of information systems and technologies.

In terms of funding, $64 \%$ of participating companies

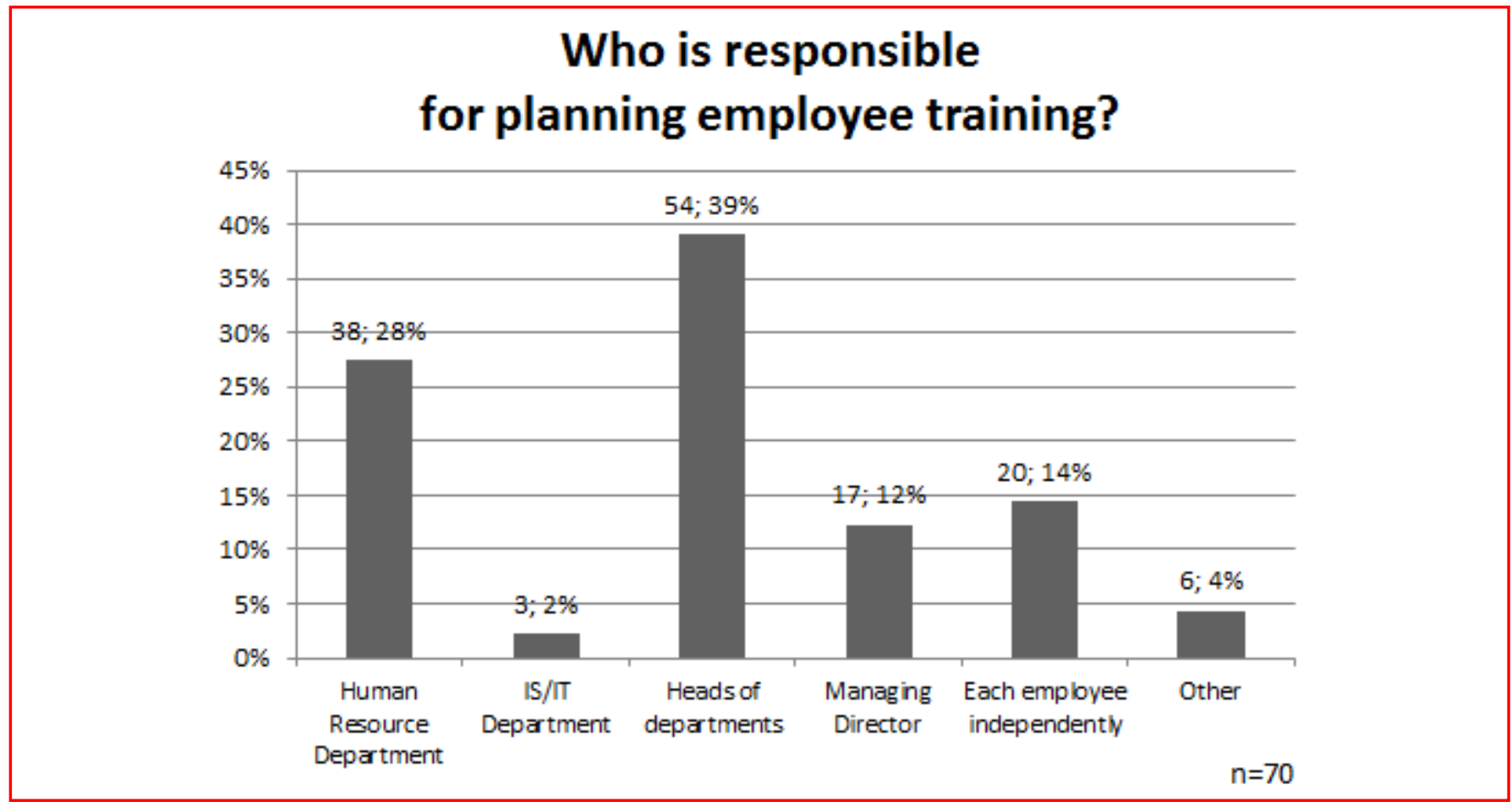

Data source: Web Survey

Figure 5: Planning of employee training 
reserve an annual budget of $€ 500$ or less per employee (Figure 6). Only in $15 \%$ of cases did the budget exceed $€ 1,000$ per employee (corresponding to 11 respondents). Among these, the financial and insurance industries were most prominent, followed by the IS/IT sector and, remarkably, trade, maintenance and servicing of motor vehicles. It may be concluded that the intense development and frequent appearance of new products and services encourages these industries to invest proportionally more in training. $12 \%$ of respondents provided no answer or were not familiar with the matter.

\section{Use of e-learning}

The survey revealed that $44 \%$ of respondents make use of e-learning (Figure 7).

The e-learning training models are mostly used by companies with over 1,000 employees (as many as $77 \%$ of the respondent companies in this category of size).

It may be concluded that e-learning is considered to be comparable to traditional training models by these larger companies. However, surprisingly, only $11 \%$ of companies with 500-1,000 employees use e-learning methods.

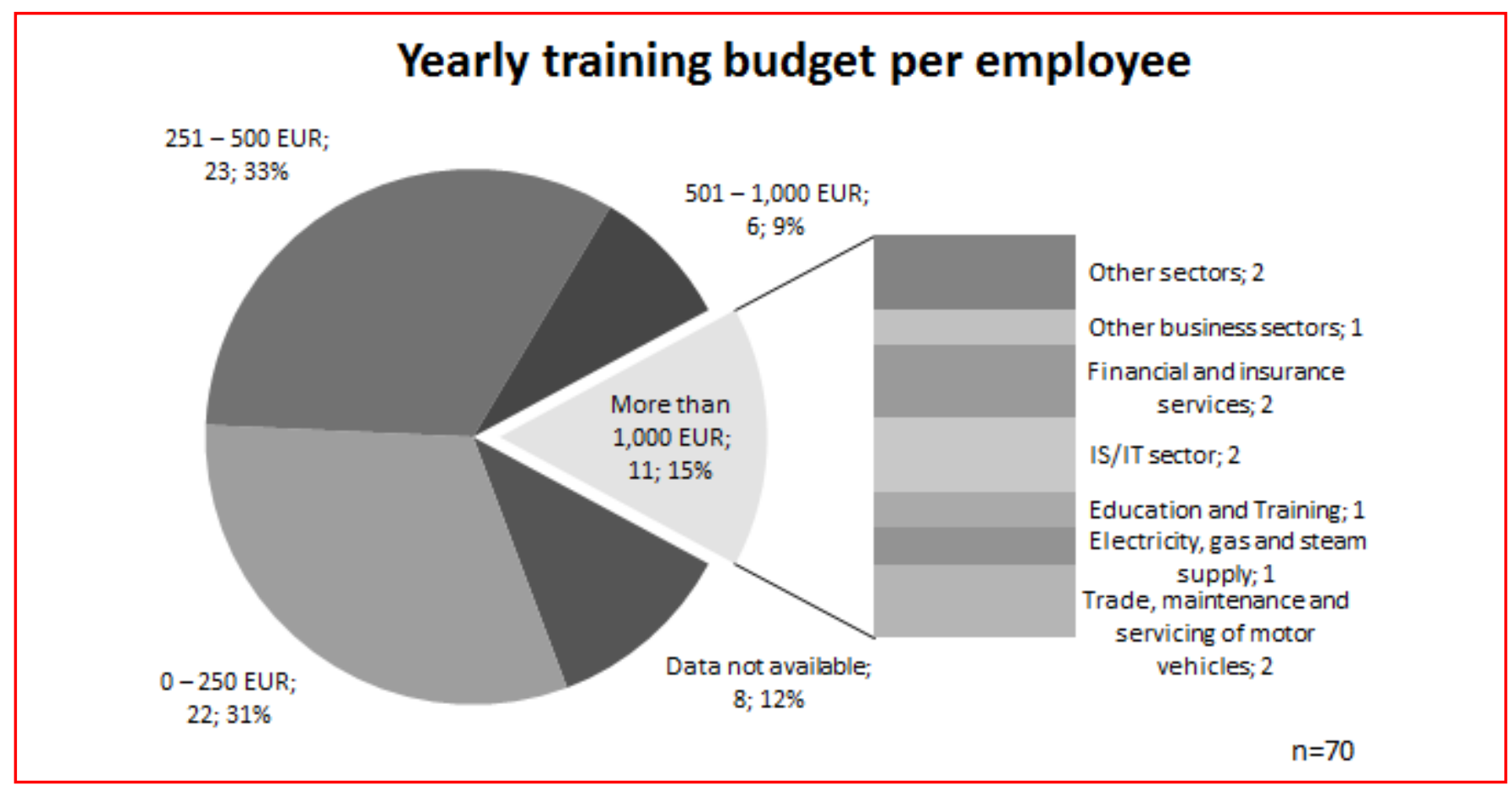

Data source: Web Survey

Figure 6: Yearly training budget per employee

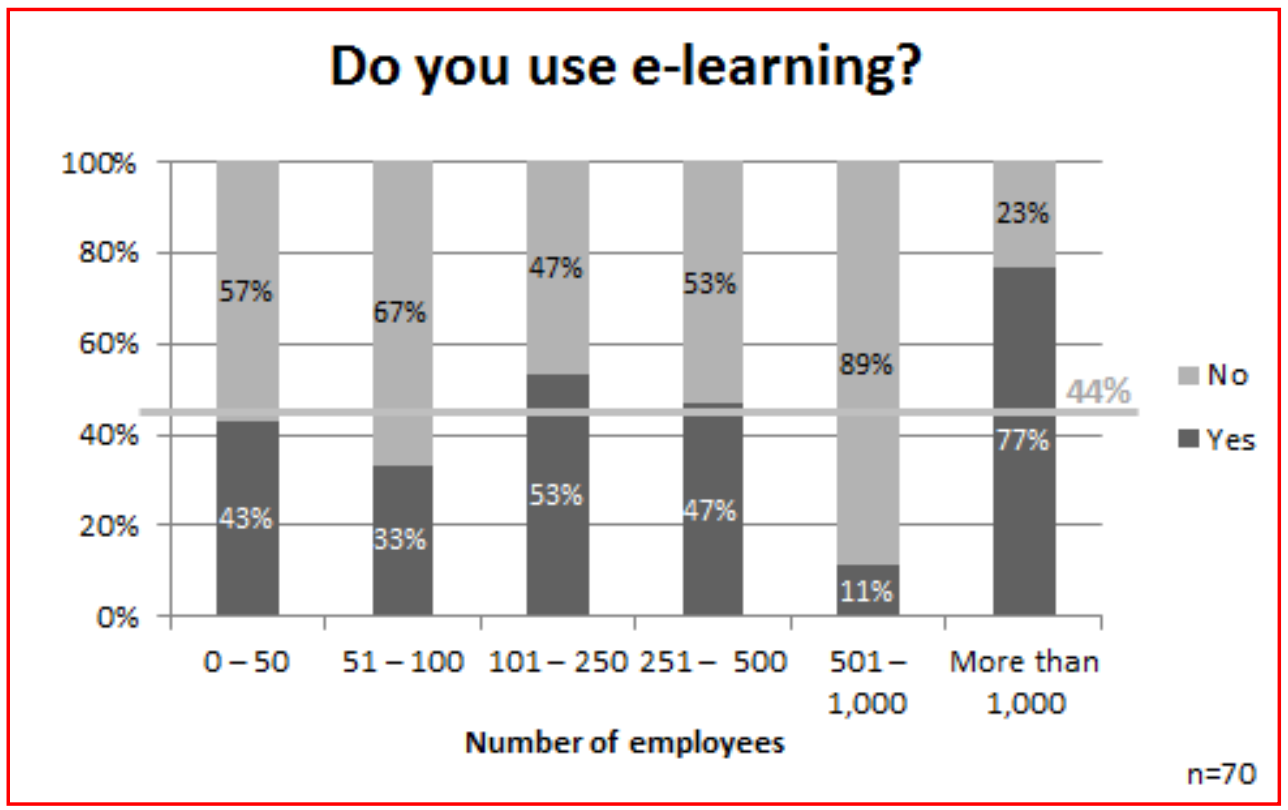

Data source: Web Survey

Figure 7: Use of e-learning by company size 
In contrast, the number of small businesses (50 people or less) using e-learning methods is remarkably high. These companies appear to be encouraged by its flexibility and relative low costs.

$75 \%$ of companies who are currently using e-learning methods (Figure 8) have been doing so for up to 5 years (less than a year in 19\% of cases). It is evident that this rate is growing. Many companies view e-learning as an increasingly viable alternative to traditional training methods. The relatively large proportion of companies that have only recently started using e-learning (one year or less) revealed that this has probably been encouraged by the current financial crisis and shortages in training budgets. Thus, elearning is also gaining popularity due to its greater cost efficiency.

$75 \%$ of the 32 companies using e-learning invest less than $20 \%$ of their training budgets toward this method (Figure 9). Although lower, these figures are quite comparable with the European corporate average. From existing surveys, e-learning budgets account for an average share of less than $10 \%$ of the entire training budget (CrossKnowledge 2012). With these percentages being rather low at the moment, their growth may be predicted in the years to come.

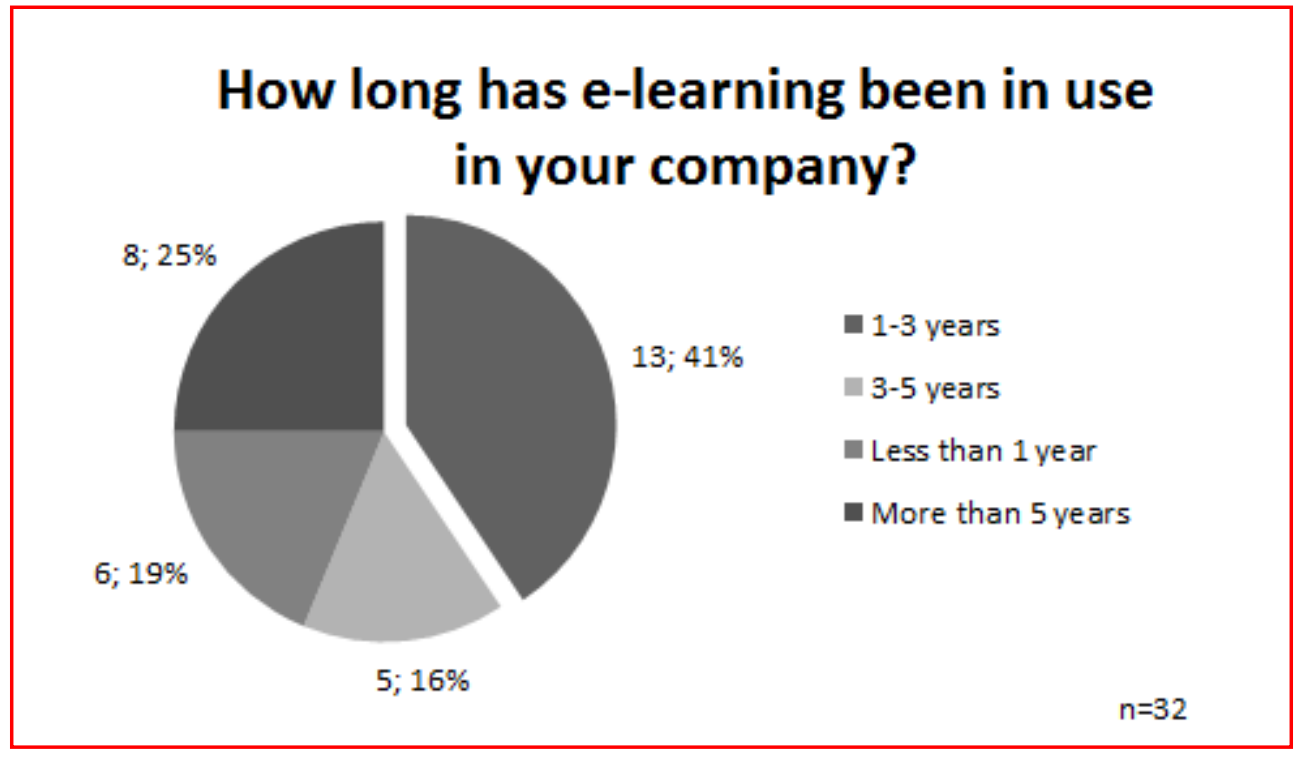

Note: From this point, only those respondents who declared they were using e-learning methods are included.

Data source: Web Survey

Figure 8: How long have e-learning methods been in use?

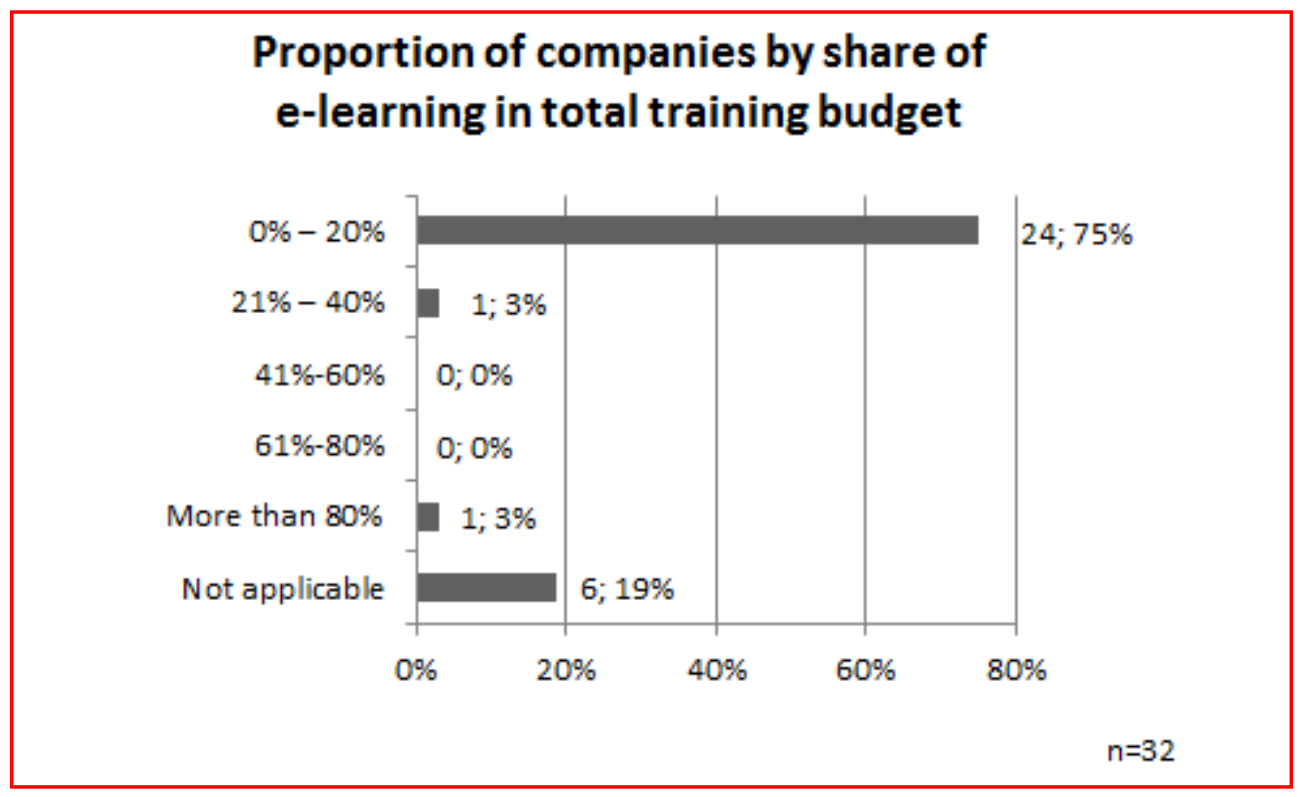

Note: From this point, only those respondents who declared they were using e-learning methods are included.

Data source: Web Survey

Figure 9: Companies by allocated share of total training budget toward e-learning 


\section{Prevalence of e-learning methods}

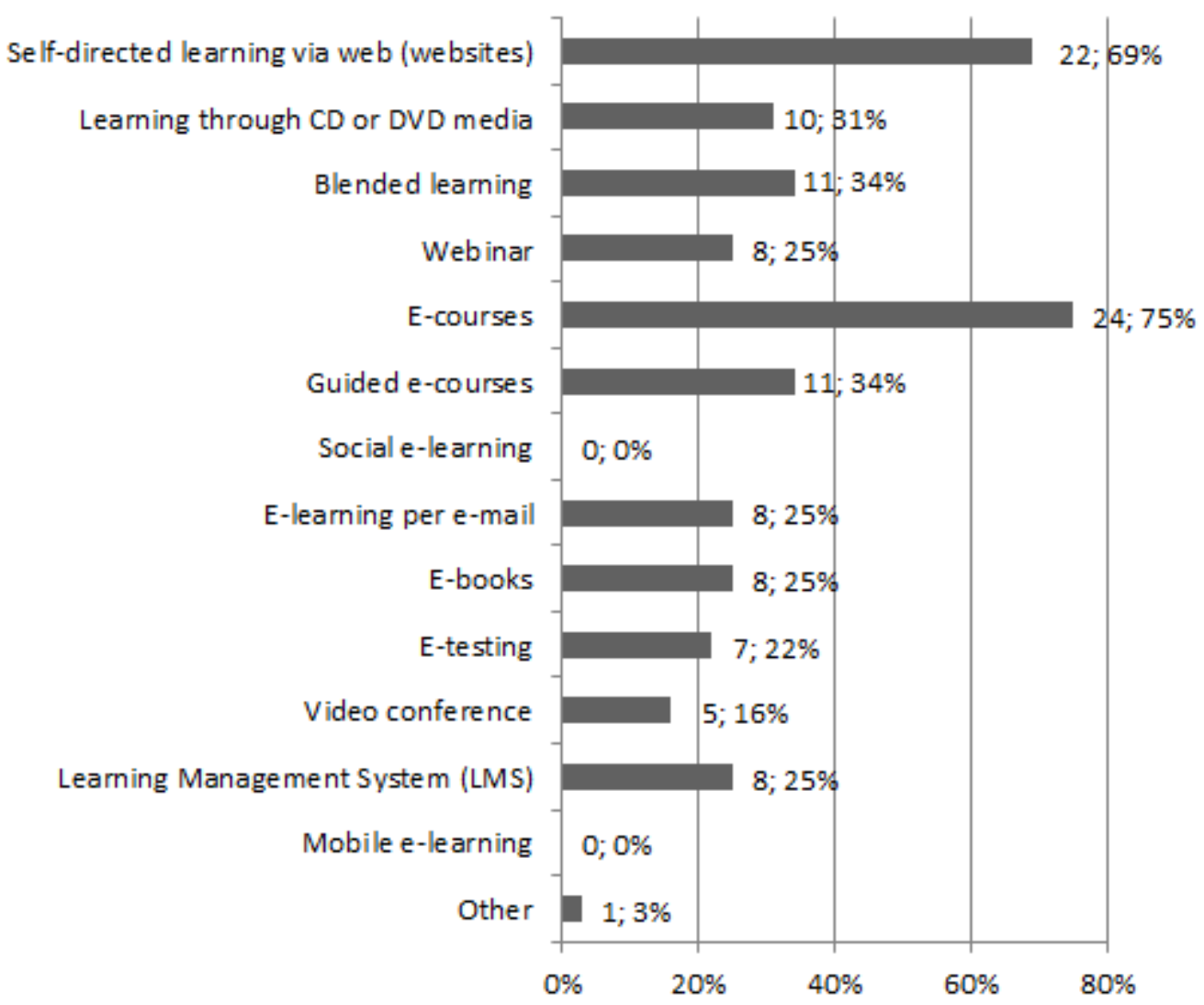

Note: From this point, only those respondents who declared they were using e-learning methods are included.

Data source: Web Survey

Figure 10: Prevalence of e-learning methods in companies

Of the different e-learning methods available, Slovene companies mostly (75\%) use e-courses (Figure 10). This can be considered a positive sign because this form is considered to be one of the more advanced options. Self-directed learning through websites accounts for up to $69 \%$, while, blended learning covers $34 \%$. Concerning the latter, a remarkable fact is that the European average is much higher; no less than $75 \%$ of companies use blended learning methods (CrossKnowledge 2012).

In Slovenia, $25 \%$ of respondents use LMS. This might be due to the companies' long-term interest in promoting an e-learning concept. Again, this rate is far beneath the European average, where $60 \%$ of companies use LMS (Overton and Dixon 2011, p. 5). In our view, the main reason for such a discrepancy lies in average company size and dispersion of business units, with the average European company much larger in size when compared to Slovenian companies. As stated earlier, company size is definitely one of the key factors for investing in LMS.

Surprisingly, not a single respondent uses social or mobile e-learning methods. This outcome grows more interesting when compared to other European countries (Overton and Dixon 2011, p. 5), where up to $45 \%$ of companies already use mobile e-learning technologies, with this share expected to increase further, up to $80 \%$, within the next two years.

From this survey, only 8 of the responding companies make use of an internal e-learning system (LMS). Half of these companies employ over 1,000 people (Figure 11).

Most of the companies that already use LMS feature a large number of branches or locations (more than 50). Hence company size and the dispersion of its premises appear to be influential factors when deciding whether or not to implement LMS.

Twenty-seven percent of the responding companies that already use e-learning methods declared that they have not only implemented the system but they also promote its use (Figure 12). Ten percent of these companies also integrate their comprehensive e-learning functions with several other business processes. E-learning is constantly and actively used by their staff. 


\section{Proportion of companies using LMS by their size and number of locations/branches}

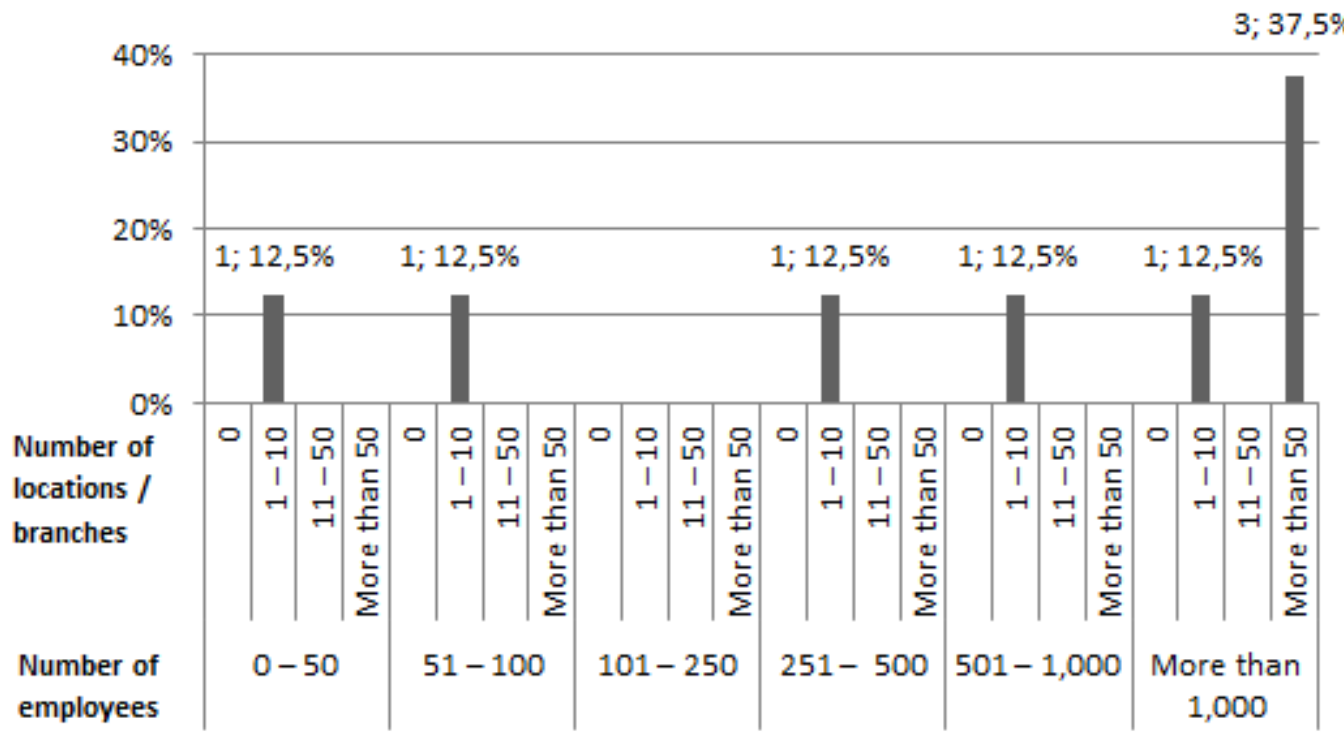

Note: From this point, only those respondents who declared they were using e-learning methods are included. Their structure is as follows: Total $=8$ (of which 3 are from the category of over 1,000 staff members and more than 50 locations; 1 with over 1,000 staff and 1-10 locations; and 1 in each of the categories 0-50, 51-100, 251-500 and 501-1,000 of employees.

Data source: Web Survey

Figure 11: Companies using LMS by their size and number of locations or branches

\section{E-learning development stage of the company}

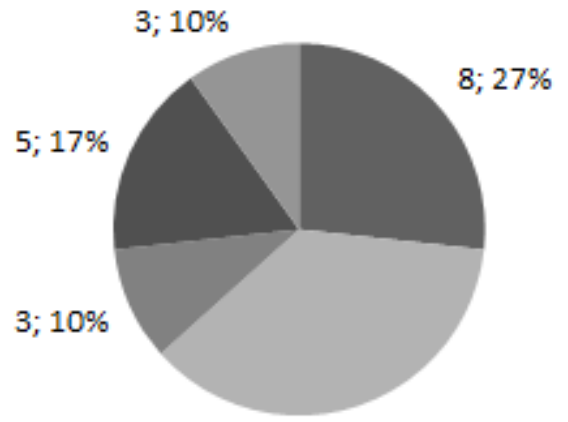

$11 ; 37 \%$

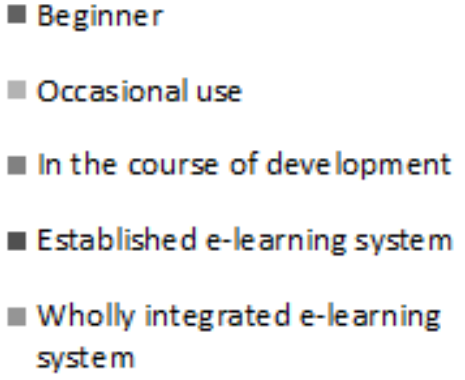

Beginner

Occasional use

In the course of development

- Established e-learning system

Wholly integrated e-learning system

Note: From this point, only those respondents who declared they were using e-learning methods are included.

Data source: Web Survey

Figure 12: Companies by stage of e-learning 


\begin{tabular}{|c|c|c|c|c|c|}
\hline \multirow{2}{*}{ What is the impact of e-learning on your business? } & \multicolumn{5}{|c|}{ Rating } \\
\hline & 1 & 2 & 3 & 4 & 5 \\
\hline Employees' skills upgraded & $\begin{array}{c}1 \\
(4 \%)\end{array}$ & $\begin{array}{c}3 \\
12 \%)\end{array}$ & $\begin{array}{c}7 \\
(28 \%)\end{array}$ & $\begin{array}{c}11 \\
(44 \%)\end{array}$ & $\begin{array}{c}3 \\
(12 \%)\end{array}$ \\
\hline Improved customer satisfaction & $\begin{array}{c}3 \\
(12 \%)\end{array}$ & $\begin{array}{c}3 \\
(12 \%)\end{array}$ & $\begin{array}{c}9 \\
(38 \%)\end{array}$ & $\begin{array}{c}7 \\
(29 \%)\end{array}$ & $\begin{array}{c}2 \\
(8 \%)\end{array}$ \\
\hline Improved efficiency in compliance of operations & $\begin{array}{c}2 \\
(8 \%)\end{array}$ & $\begin{array}{c}2 \\
(8 \%)\end{array}$ & $\begin{array}{c}7 \\
(29 \%)\end{array}$ & $\begin{array}{c}7 \\
(29 \%)\end{array}$ & $\begin{array}{c}6 \\
(25 \%)\end{array}$ \\
\hline $\begin{array}{l}\text { Decreased number of accidents, misuses and risks } \\
\text { (safety at work area) }\end{array}$ & $\begin{array}{c}6 \\
(25 \%)\end{array}$ & $\begin{array}{c}4 \\
(17 \%)\end{array}$ & $\begin{array}{c}7 \\
(29 \%)\end{array}$ & $\begin{array}{c}5 \\
(21 \%)\end{array}$ & $\begin{array}{c}2 \\
(8 \%)\end{array}$ \\
\hline $\begin{array}{l}\text { Decreased number of accidents, misuses and risks (infor- } \\
\text { mation security area) }\end{array}$ & $\begin{array}{c}3 \\
(13 \%)\end{array}$ & $\begin{array}{c}2 \\
(9 \%)\end{array}$ & $\begin{array}{c}8 \\
(35 \%)\end{array}$ & $\begin{array}{c}8 \\
(35 \%)\end{array}$ & $\begin{array}{c}2 \\
(9 \%)\end{array}$ \\
\hline Easier access to information on new products and services & $\begin{array}{c}3 \\
(13 \%)\end{array}$ & $\begin{array}{c}3 \\
(13 \%)\end{array}$ & $\begin{array}{c}3 \\
(13 \%)\end{array}$ & $\begin{array}{c}7 \\
(30 \%)\end{array}$ & $\begin{array}{c}7 \\
(30 \%)\end{array}$ \\
\hline Training costs reduced & $\begin{array}{c}0 \\
(0 \%)\end{array}$ & $\begin{array}{c}3 \\
(12 \%)\end{array}$ & $\begin{array}{c}3 \\
(12 \%)\end{array}$ & $\begin{array}{c}7 \\
(29 \%)\end{array}$ & $\begin{array}{c}11 \\
(46 \%)\end{array}$ \\
\hline No measuring / data not available & $\begin{array}{c}4 \\
(16 \%)\end{array}$ & $\begin{array}{c}5 \\
(20 \%)\end{array}$ & $\begin{array}{c}6 \\
(24 \%)\end{array}$ & $\begin{array}{c}2 \\
(8 \%)\end{array}$ & $\begin{array}{c}8 \\
(32 \%)\end{array}$ \\
\hline No impact & $\begin{array}{c}8 \\
(36 \%)\end{array}$ & $\begin{array}{c}8 \\
(36 \%)\end{array}$ & $\begin{array}{c}4 \\
(18 \%)\end{array}$ & $\begin{array}{c}1 \\
(5 \%)\end{array}$ & $\begin{array}{c}1 \\
(5 \%)\end{array}$ \\
\hline
\end{tabular}

Rating (1 - do not agree, 2 - partly agree, 3- mostly agree, 4 - agree, 5 - very much agree)

Data source: Web Survey

Table 1: Impact of e-learning on business

However, many companies that use e-learning methods use it sporadically (in $37 \%$ of cases), or are in the course of development within the project (10\%), or have just started using it (27\%). These three groups of users represent $74 \%$ of all companies who already use e-learning. Experiences from the US and other major markets indicate that the Slovene e-learning market is in a growth stage and that its potential is still high. However, when predicting future trends, market specifics must be taken into account, such as the structure

When asked about the impact of e-learning on their businesses and outcomes (Table 1), almost half of the respondents (46\%) agree that e-learning is keeping their corporate training costs down (rating $=5$ out of 5 ), while none of the respondents stated the opposite.

Many companies (79\% of all rating 3 or more) described improved IS/IT-security, i.e. decrease in accidents, misuse and risks effected by e-learning. Companies also attributed their improved efficiency to the better compliance of operations ( $83 \%$ of those who rated 3 or more) and upgraded skills of employees, with both being positive effects of e-learning.

As an additional comment, it should be stated that an over-proportionate number of the companies do not systematically measure such kinds of effects, and were unable to obtain the necessary data, or had none available. Following the experiences of the developed markets, such as the US, where such metrics are integrated in all business processes, this result is quite surprising and could lead toward further questions over how far the users' own approximate estimations of the e-learning effects have been provided in place of measured values.

When asked to compare e-learning to traditional training methods and to name the most evident benefits, companies responded: reduced cost of training (78\%); improved user flexibility (78\%); improved access to training content (72\%); and less absenteeism (69\%),

On the other hand, e-learning is not perceived as leading to higher quality levels when compared to traditional methods. Studies of other European companies show the opposite: in $61 \%$ of cases they claim e-learning has indeed improved the quality of their training processes (Overton and Dixon 2011, p. 10). Recalling the research findings by Vehovar (2007, p. 25) might help to explain this point, given the predominant role of the teacher in education systems in Slovenia. However, e-learning is mostly performed as self-paced learning, with a more or less passive role on the part of the teacher and by using an asynchronous concept of communication. To achieve success, participants are required to act autonomously.

Therefore, the increasing popularity of e-learning appears to be based primarily on two characteristics, location independence and cost efficiency. It should also be stated, that only $2 \%$ of the respondents confirmed that e-learning had no benefit at all.

Of the major obstacles in implementation of e-learning and related technologies (Figure 14) stated by the companies, issues related to human resources were considered to 


\section{Main benefits of e-learning}

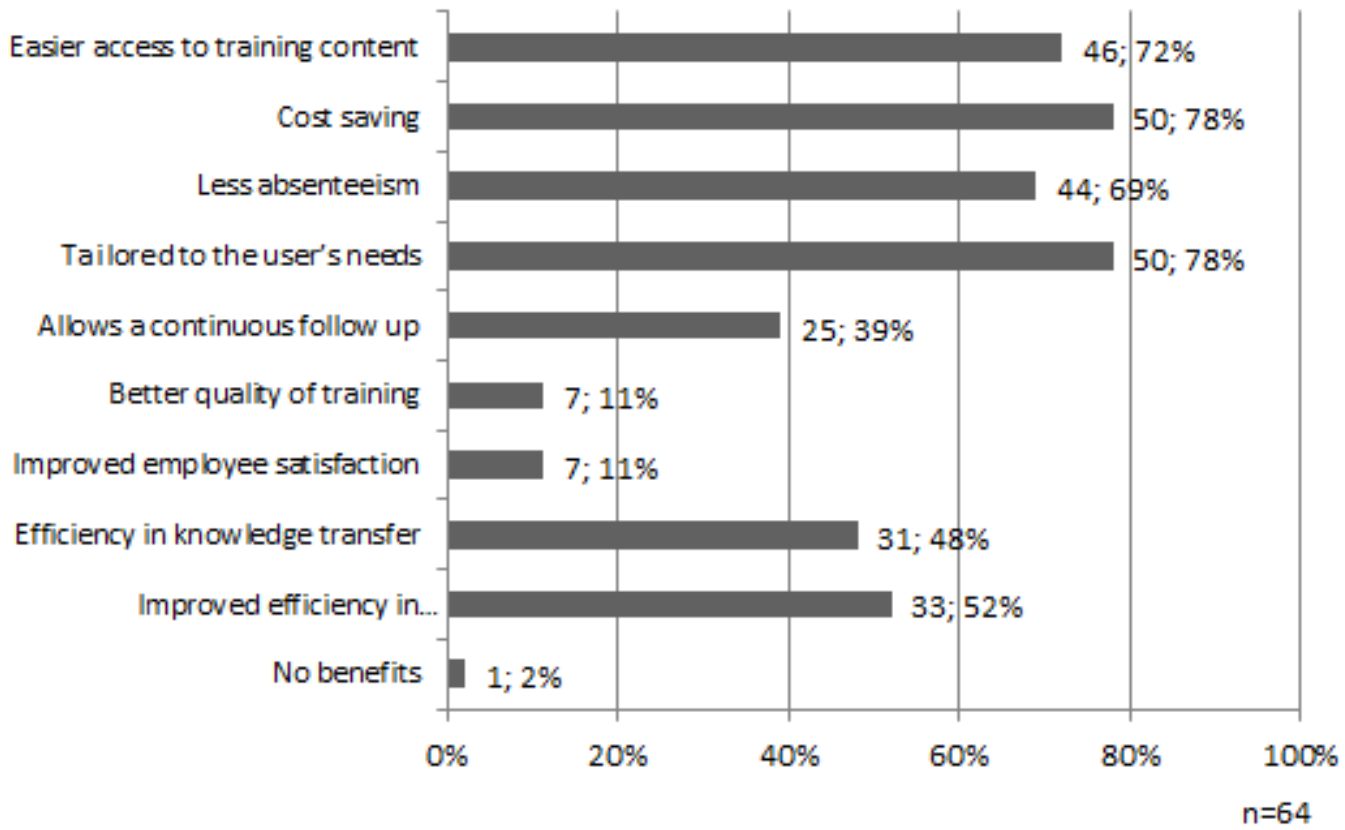

Data source: Web Survey

Figure 13: Main benefits of e-learning compared to traditional methods

\section{Main obstacles to implementation of e-learning technologies}

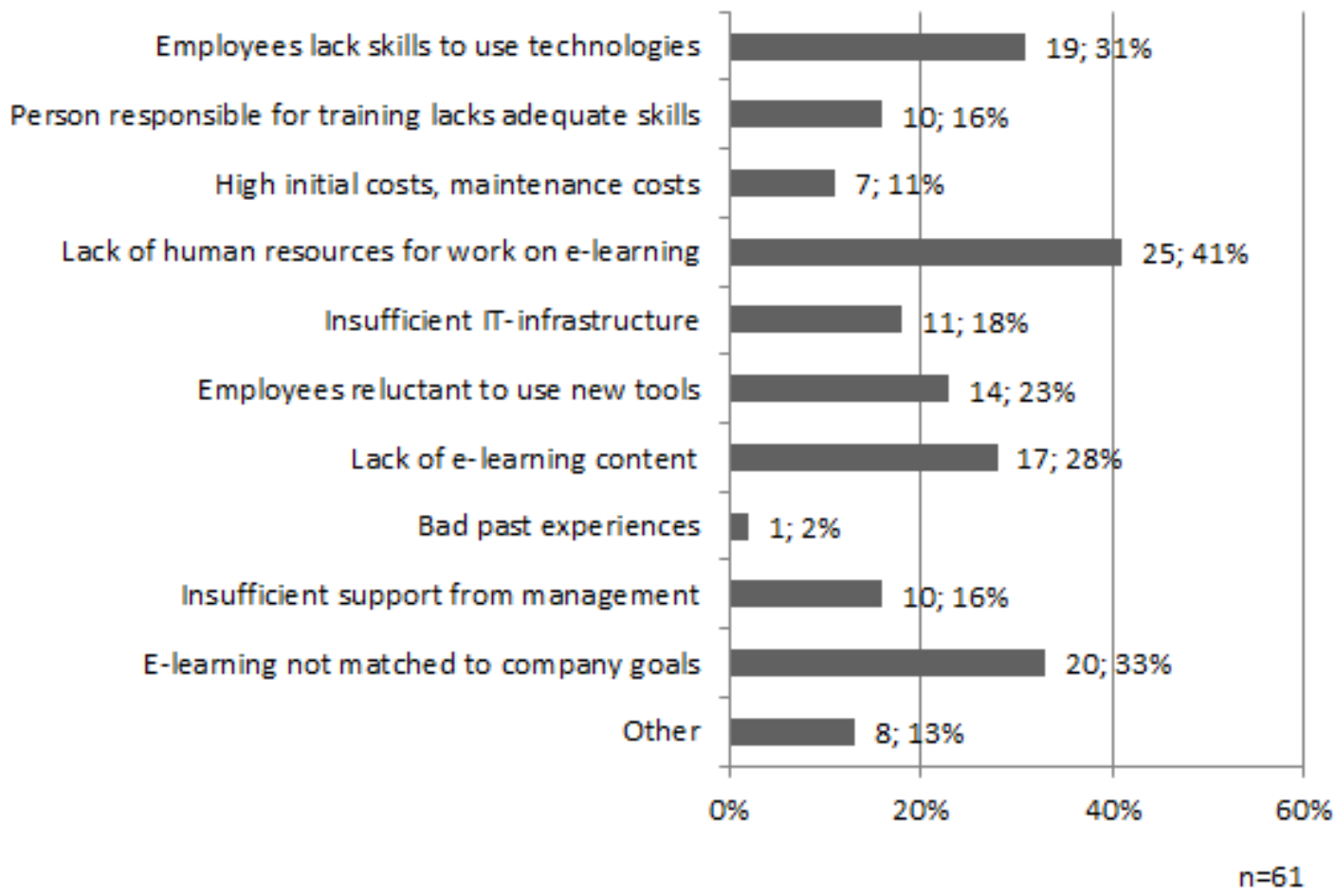

Data source: Web Survey

Figure 14: Main obstacles to implementation of e-learning technologies 
be the most important. Forty- one percent of cases stated an insufficient number of staff were available to work on e-learning. This claim was confirmed also by the outcome of the "Sources of e-learning content" section. Most companies seem to use products that are already available or outsourced these services and to a much lesser extent, had their own in-house production of content.

Remarkably, many respondents indicated that the implementation of e-learning technologies was "simply not considered to match the company's strategic goals" (33\%) or claimed that there was a lack of skills necessary to use these new technologies (31\%). Surprisingly, the latter statements

\section{E-learning contents by prevalence of their use today and in 2 years}

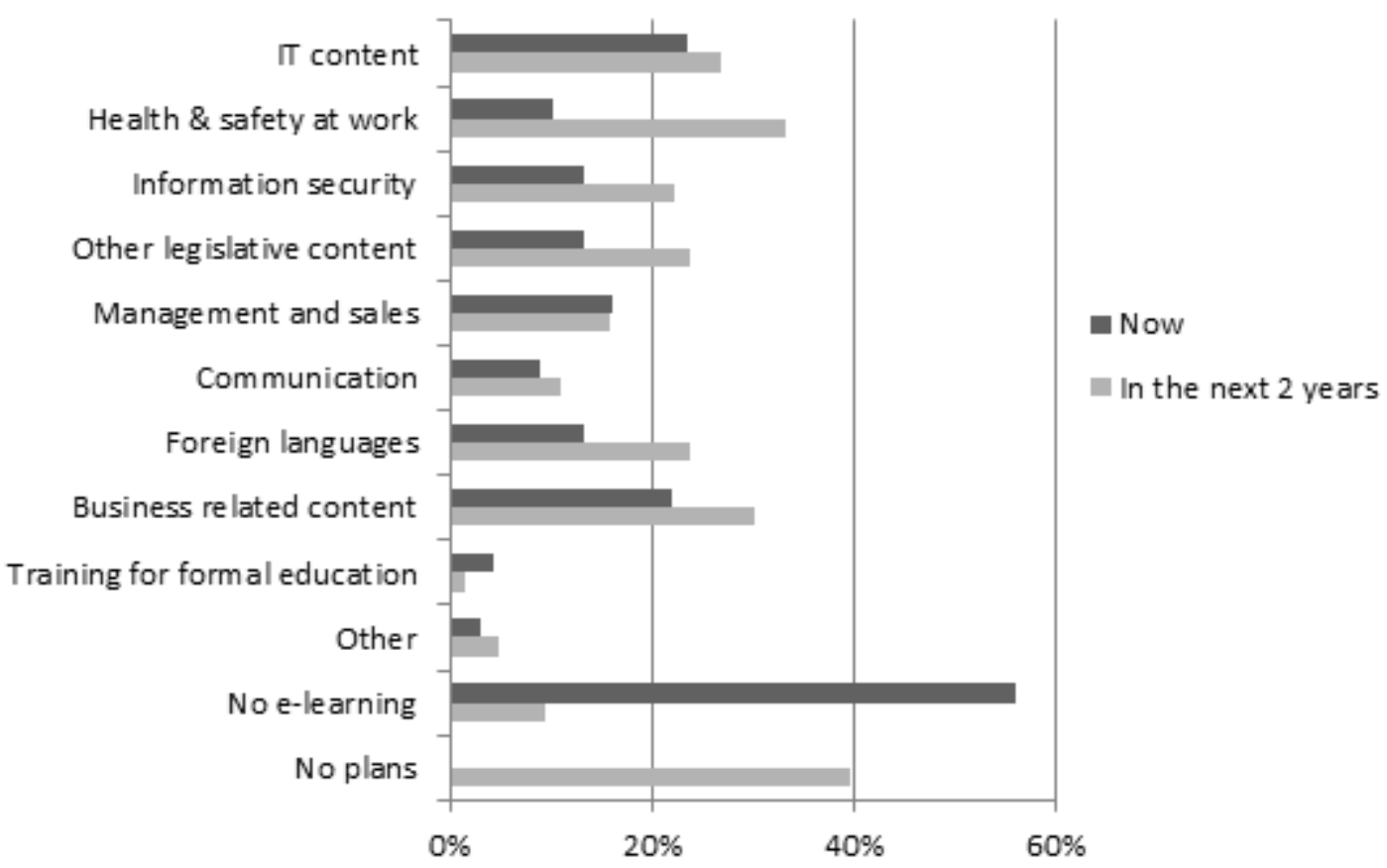

Data source: Web Survey

Figure 15: E-learning content by current use versus planned use

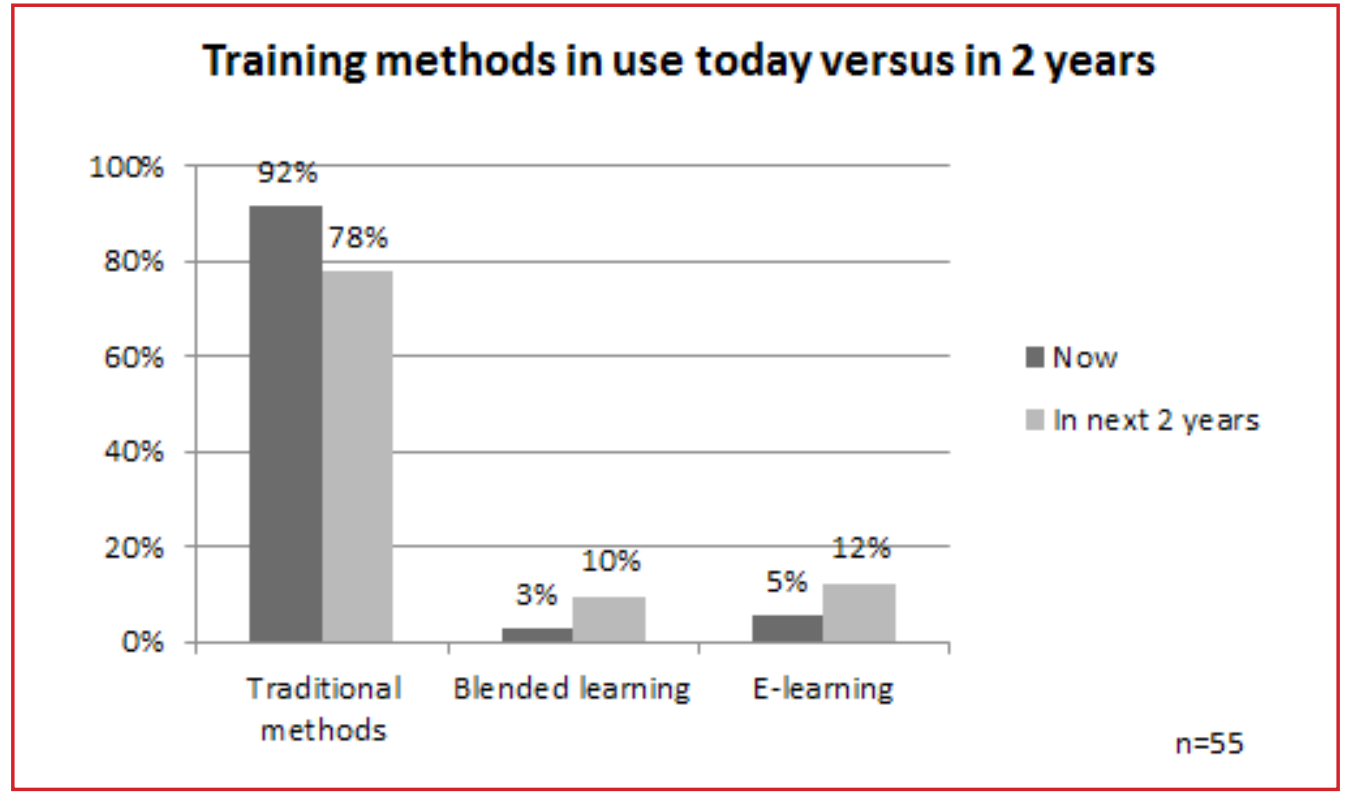

Data source: Web Survey

Figure 16: Training methods today versus the next 2 years by hours of training a growing share to blended learning and e-learning methods. 
do not match at all with the outcomes of recent studies on ICT-literacy in Slovenia. On the other hand, they are supported by experience elsewhere in Europe. An even higher percentage of companies analyzed by Overton and Dixon (2011, p. 13) found these factors to be obstacles; as many as $60 \%$ described a lack of skills from the employee to manage his/her own training process.

In Slovenia, only $2 \%$ of the respondents cited any kind of bad experience. This could mean that all companies have mostly good, if not excellent, experiences with e-learning.

In response to the area of application, most (24\%) companies use e-learning methods for IS/IT-related content (Figure 15). Content related to compliance in operation represents the second most important area of application, including health and safety at work, information security and "other legislative content."

Companies tend to rely increasingly on e-learning methods and it may be expected that this trend will increase further in the future. This can be expected for all fields of corporate training, except management, sales and acquiring formal education. The greatest growth can be expected for content related to compliance training. Thirty three percent of companies intend to use e-learning for staff health and safety training in the next 2 years (today: 10\%). Information security, "other legislative content" and foreign languages follow. Stable or slightly downward trends are expected for the areas of communication, management and sales. The reason might be that electronic knowledge transfer is rather more difficult in these areas.

It is interesting that only $10 \%$ of companies have decided not to use e-learning during the next 2 years and $40 \%$ have no plans as yet. Nevertheless, more companies are expected to use e-learning methods at the end of the next 2 year period than the current one.

Comparing the hours of training invested in e-learning today and in 2 years (Figure 16) confirms a growing trend in e-learning compared with traditional methods. Therefore, companies expect that time invested in traditional training will drop to $78 \%$ on the basis of

Therefore, it can be assumed that traditional learning methods will gradually give way to various e-learning methods, either pure e-learning or blended learning.

\section{CONCLUSIONS}

E-learning has become a generally accepted form of training in Europe and worldwide for both formal education and corporate training. Traditional learning methods are giving way to e-learning. Growth rates are of particular interest in emerging markets.

Trends in Slovenia are comparable to those of the major markets. This means that e-learning is gaining status as a viable alternative in Slovene companies who appreciate benefits such as cost efficiency and flexibility. However, elearning is not yet perceived to give better quality training. Such a perception is rather remarkable, with companies elsewhere in Europe observing improved quality of training through e-learning methods.
The results also showed that Slovene companies use different e-learning methods, but not all that are currently available. Particularly surprising was the almost complete absence of e-learning through mobile technologies, which are achieving high growth rates elsewhere in the world. Acceleration in this area can be expected in Slovenia within a few years.

In some parameters, Slovenia seems to compare reasonably well to the European average. This can be said when speaking of the widespread use of the e-learning concept, its content and to some extent the trends of traditional methods giving way to e-methods. Lagging behind the international trends is the use of comprehensive e-learning methods and Learning Management Systems (LMS). Small to average company size, dispersion of business sites and a lack of adequate experts seem to be the most plausible explanations for this.

Arguments reinforcing use, such as recent trends and especially cost efficiency during the current financial crisis, provide strong signals that point to the great potential for e-learning in the corporate environment of Slovenia.

\section{REFERENCES}

Adkins, S. S. 2011. The Worldwide Market for Self-paced eLearning Products and Services: 2010-2015 Forecast and Analysis. Ambient Insight. (database online) http://www.ambientinsight.com/Resources/Documents/Ambient-Insight-20102015-Worldwide-eLearning-Market-Executive-Overview.pdf. (accessed November 5, 2012).

Arh, T., Kovačič, M. and Jerman-Blažič, B. 2006. Struktura ponudbe e-izobraževanja v Sloveniji. Ljubljana: Institut »Jožef Stefan«, Laboratorij za odprte sisteme in mreže. (database online) http://uploadi.www.ris.org/editor/1164734009Arh_Tanja.pdf. (accessed October 25, 2012).

Bachman, K. 2000. Corporate e-learning: exploring a new frontier. (database online) http://www.internettime.com/Learning/articles/hambrecht.pdf.pdf. (accessed October 16, 2012).

Commission of the European Communities. 2001. The eLearning Action Plan: Designing tomorrow's education. (database online) http:// ec.europa.eu/education/archive/elearning/annex en.pdf. (accessed October 30, 2012).

Cox eLearning Consultants, LLC. 2012. Industry Buying Plans\&Trends for 2012: Social Learning, Video Training, Mobile Learning and Web Conferencing. Cox eLearning Consultants, LLC. (database online) https://news.citrixonline.com/wp-content/uploads/2012/02/Industry_Buying_Plans-Trends_2012. pdf. (accessed November 28, 2012).

CrossKnowledge. 2012. 1st European e-learning Barometer. (database online) http://www.crossknowledge.com/en_GB/elearning/media-center/news/elearning-survey-barometer.html. (accessed November 28, 2012)

Defining e-learning. 2012. (database online) http://www.nwlink. com/ donclark/hrd/elearning/define.html. (accessed November 6, 2012).

Delo.si.. 2010. Podjetja z največjim številom zaposlenih. (database online) http://www.delo.si/assets/media/other/20110606//06 01 66SteviloZaposlenih.pdf. (accessed November 22, 2012). 
Ed Technology Glossary of Terms. 2012. (database online) http://www.uen.org/core/edtech/glossary.shtml (accessed November 24, 2012).

Eizobraževanje.net. 2011. Raziskava o e-izobraževanju v slovenskih podjetjih. (database online) http://www.eizobrazevanje.net/ raziskava-o-e-izobrazevanju-v-slovenskih-podjetjih/ (accessed October 12, 2012).

Elearning - What is E-learning? 2012. (database online) http:// www.cognitivedesignsolutions.com/ELearning/E-Learning1. htm (accessed November 30, 2012).

Gardner, J., and Holmes, B. 2006. E-Learning: Concepts and Practice. London: Sage Publications Ltd.

Hart, J. 2009. Social Learning. (database online) http://www.slideshare.net/janehart/the-future-of-elearning-is-social-learning (accessed November 26, 2012).

Howstuffworks. 2012. (database online) http://money.howstuffworks.com/business-communications/how-web-seminarswork.htm. (accessed March 28, 2013).

Overton, L., and Dixon, G. 2011. Learning technology adoption in European Businesses 2011. Berlin: Online Educa Berlin, Towards Maturity. (database online) http://www.icwe.net/ oeb_special/OEB_Newsportal/wp-content/uploads/2011/11/ Online-Educa-towards-Maturity-report-2011-v6-PDF_FINAL. pdf. (accessed November 5, 2012).

Unesco. 2012. ICT in Education. (database online) http://www.unesco.org/new/en/unesco/themes/icts/m4ed (accessed March 7,2013).

Vehovar, V. 2007. eLearning in Slovenia. Ljubljana: Fakulteta za družbene vede.

\section{Appendix 1:}

\section{List of questions for Web survey}

(Note: options not shown, as seen from the responses):

1. What is the main activity of your company?

2. How many employees work in your company?

3. What is your function in the company?

4. How many locations or branches does your company have (local, international business units, subsidiaries)?

5. What is the budget allocation per year per employee invested in training (including fees, travel costs, daily allowances)?

6. Who is responsible for planning employee training in your company? (multiple answers are possible)

7. How often are the employees of your company trained?

8. For how long have you been using e-learning methods in your company?

9. What percentage of your entire training budget is allocated for e-learning?

10. What forms of e-learning do you use in your company (multiple answers are possible)?

11. What content is supported by e-learning methods for employee training in your company? (multiple answers possible)?

12. What proportion of time is used for the different forms of e-learning in your company (in terms of hours invested)?

13. Who performs e-learning in your company? (multiple answers are possible)

14. What impact does (did) e-learning have on your business? Please rate each of the statements from 1 to 5 (1 - I don't agree at all; 5 - very much agree)

15. Which stage of use of e-learning methods is your company in?

16. What are the main benefits of e-learning compared to traditional methods for your company? Please select the best matched answers.

17. What are (were) the main obstacles for implementing e-learning technologies in your company? Please select the best matched answers.

18. Which content do you plan to integrate in your e-learning process in the next 2 years? (multiple answers are possible)

19. In terms of training hours, what proportion of time for each of the training forms (methods) do you plan for your company? 